\title{
Perioperative temperature measurement and management: moving beyond the Surgical Care Improvement Project
}

\author{
Joshua W. Sappenfield ${ }^{1 *}$, Caron M. Hong ${ }^{2}$ and Samuel M. Galvagno ${ }^{3}$ \\ *Correspondence: JSappenfield@anes.umm.edu \\ 'Trauma Anesthesiology Fellow, R Adams Cowley Shock Trauma Center, Department of Anesthesiology, University of Maryland \\ Medical Center, Baltimore, Maryland, USA. \\ ${ }^{2}$ Department of Anesthesiology, Division of Critical Care Medicine, University of Maryland Medical Center, Baltimore, Maryland, USA. \\ ${ }^{3}$ Division of Trauma Anesthesiology, R Adams Cowley Shock Trauma Center, Program in Trauma, And Division of Critical Care \\ Medicine, Department of Anesthesiology, University of Maryland Medical Center, Baltimore, Maryland, USA.
}

\begin{abstract}
Intraoperative management of patient body temperature is a standard of care for practicing anesthesiologists. Merely complying with the Surgical Care Improvement Project (SCIP) measurement is inadequate for optimizing perioperative outcomes. Clinicians should have a sound understanding of available temperature monitoring sites, deleterious effects of hypothermia, and indications for therapeutic hypothermia. This foundation will help physicians use indicated modalities to improve patient outcomes throughout the perioperative period. The purpose of this paper is to review appropriate intraoperative temperature monitoring, the importance of maintaining normothermia, and indications for intraoperative hypothermia.
\end{abstract}

Keywords: Perioperative temperature management, surgical care improvement project (SCIP), hypothermia, hyperthermia, normothermia

\section{Introduction}

Temperature monitoring is a standard of care as well as a part of the American Society of Anesthesiologists' guidelines for anesthetic management. Anesthesiologists are expected to be proactive in recognizing and managing temperature derangements throughout the perioperative period $[1,2]$. The purpose of this paper is to review appropriate intraoperative temperature monitoring, the importance of maintaining normothermia, and indications for intraoperative hypothermia.

In an effort to regulate perioperative practice, the Centers for Medicare and Medicaid Services have endorsed the Surgical Care Improvement Project (SCIP) measurements. One SCIP measure is related to the number of patients whose body temperature is greater than $36^{\circ} \mathrm{C}$ after undergoing anesthesia for longer than one hour [1]. For anesthetics lasting greater than one hour, either forced-air heated devices or warm-water garments should be employed to help maintain normothermia [1]. The only exceptions to the SCIP measure are documentation of intentional hypothermia, monitored anesthesia care, or peripheral nerve block [1]. The SCIP measure was created because intraoperative hypothermia has been associated with an increase in surgical site infections (SSIs), post-operative cardiac events, intraoperative blood loss, transfusion requirements, time to recover from anesthesia, and a decrease in the metabolism of common anesthetics [5-13].
Once anesthetized, a patient's autoregulatory and behavioral thermoregulatory mechanisms are compromised. Therefore, anesthesiologists should be familiar with the accuracy and reliability of commonly used monitoring sites. Additionally, anesthesiologists should have an understanding of strategies for altering patient core temperature. While the SCIP measure does permit clinically-indicated intentional hypothermia, the anesthesiologist should be knowledgeable about how to minimize the risks of adverse events related to hypothermia.

\section{Intraoperative temperature monitoring and its limitations}

Effective perioperative temperature management begins with accurate temperature measurement. SCIP measurement does not indicate which temperature site is the most appropriate to monitor as long as it represents core body temperature [1]. Anesthesiologists should be proficient in understanding the advantages and limitations of contemporary measurement techniques. Probes which measure temperature should be capable of discriminating within $0.5^{\circ} \mathrm{C}$, the minimum difference shown to affect blood loss [14,15].

Temperature monitoring is measured from a plethora of sites. Sites commonly used for measurement of temperature are: skin, tympanic membrane, bladder, esophagus, nasopharynx, pulmonary artery, and jugular bulb. Each site has limitations, 
Table 1. Limitations associated with common sites for core temperature measurement. (CPB, Cardiopulmonary Bypass; AHA, American Heart Association; ${ }^{\star}$ denotes measured by infrared; $\dagger$ denotes measured by thermocouple).

\begin{tabular}{|c|c|}
\hline$\underline{\text { Site }}$ & Limitations \\
\hline Pulmonary artery & $\begin{array}{l}\text { yAffected by } \mathrm{CPB}^{16} \\
\text { Decreased for several minutes after receiving cold } \\
\text { cardioplegic solutions }^{17}\end{array}$ \\
\hline Nasopharyngeal & $\begin{array}{l}\text { Adjusts slowly to rapid changes in cerebral temperature }{ }^{17} \\
\text { Placement can cause nasal bleeding }{ }^{16}\end{array}$ \\
\hline Esophageal & $\begin{array}{l}\text { Decreased by suctioning on nasogastric/orogastric tube }{ }^{18} \\
\text { Affected by ventilation through endotracheal tubes } \\
{\text { Affected by } \mathrm{CPB}^{16}}^{16} \\
\text { Not recommended by the AHA for monitoring during } \\
\text { therapeutic hypothermia }{ }^{19}\end{array}$ \\
\hline Bladder & $\begin{array}{l}\text { Accuracy is dependent on urine output } \mathrm{t}^{20} \\
\text { Affected by intra-abdominal surgeries }{ }^{20} \\
\text { Unreliable during CPB }^{16} \\
\text { Not recommended by the AHA for monitoring of anuric } \\
\text { patients during therapeutic hypothermia }{ }^{19}\end{array}$ \\
\hline Tympanic & $\begin{array}{l}\text { Decreased by air currents }{ }^{15,16 \dagger} \\
\text { Affected by changes in skin temperature on the head and } \\
\text { face }^{17 \dagger} \\
\text { Response to temperature change is delayed by cerumen or } \\
\text { dried blood in the auditory canal }{ }^{16 \dagger} \\
\text { Probes are difficult to place correctly } \\
\text { Placement may perforate the tympanic membrane }{ }^{15^{* \dagger}} \\
\text { Not recommended by the AHA for monitoring during } \\
\text { therapeutic hypothermia } a^{19^{* \dagger}}\end{array}$ \\
\hline Rectal & $\begin{array}{l}\text { Changes more slowly than pulmonary artery, } \\
\text { nasopharyngeal, tympanic, esophageal, and } \\
\text { bladder }{ }^{15,17} \\
\text { May not increase as expected during malignant } \\
\text { hyperthermia }{ }^{15} \\
\text { Can become lodged in fecal matter }{ }^{16} \\
\text { Not recommended by the AHA for monitoring during } \\
\text { therapeutic hypothermia }^{19}\end{array}$ \\
\hline $\begin{array}{l}\text { Deep Tissue } \\
\text { Thermometry }\end{array}$ & $\begin{array}{l}\text { Requires a long equilibrating time }{ }^{17,21} \\
\text { Response to rapid changes in body temperature is } \\
\text { unpredictable } \mathrm{e}^{17,21}\end{array}$ \\
\hline Skin & $\begin{array}{l}\text { Can have } 2^{\circ} \mathrm{C} \text { difference from core } e^{15} \\
\text { Changes more slowly during induction of hypothermia } \\
\text { and with rewarming compared to other monitored sites } \\
\text { Not recommended by the AHA for monitoring during } \\
\text { therapeutic hypothermia }{ }^{19}\end{array}$ \\
\hline
\end{tabular}

listed in Table 1. The primary factors to consider when appraising temperature probe locations are the level of invasiveness and the degree of accuracy. The following discussion is a description of assessment of core body temperatures ranging from the most to the least accurate measurement locations.

The temperature measured from the pulmonary artery is the most accurate location from which to measure core temperature, in the majority of circumstances, and is the gold standard for core temperature monitoring. The temperature measured from the pulmonary artery is a close approximation of the jugular bulb temperature and even correlates well during rapid changes in surgical procedures involving deep hypothermic circulatory arrest [17]. Detecting temperature from the pulmonary artery requires an invasive catheter. Since placement of a pulmonary artery catheter is associated with several severe possible complications [22,23], insertion of the catheter is indicated for hemodynamic monitoring.

Nasopharyngeal, esophageal, and urinary bladder monitoring all constitute good measurement sites. Nasopharyngeal and urinary bladder temperatures correlate well with pulmonary artery temperature except during rapid changes [17]. The temperature measured in the bladder does not reflect core temperature accurately in all patients, in fact, in some patients the measured temperature may vary more than measured skin temperature [17].

Less accurate sites include tympanic, rectal, and deep tissue thermometry. Regardless of whether the tympanic site is measured by infrared technology or with a thermocouple, it is difficult to place correctly [15]. Rectal temperature has been shown to adjust more slowly than other sites for measuring core temperature contributing to its lower accuracy $[15,17]$ The least accurate location to measure temperature is the skin as it is subject to peripheral vasoconstriction induced by thermoregulatory mechanisms in the presence of hypothermia [16]. Skin temperatures are frequently monitored because they are easily accessible. The literature supporting normothermia uses a variety of sites on the body for monitoring temperature, making it difficult to compare a single temperature measurement between the different studies. Based on the surgical procedure and patient characteristics, the anesthesiologist should incorporate the least invasive modality that will provide reliable and adequate assessment of core body temperature for the duration of the operation.

\section{Monitoring brain temperature}

Since the jugular bulb receives the majority of cerebral blood flow, it is thought to correlate to temperature in the cerebral cortex [17]. However, there is no evidence that measuring jugular bulb temperature or intraparenchymal temperature, compared to other measurements of core body temperature, improves outcomes and they are highly invasive monitors. This is interesting since intentional hypothermia is induced while monitoring core body temperature for central neuroprotection after cardiac arrest or in infants with hypoxic- ischemic encephalopathy $[19,24]$.

In certain circumstances, such as severe brain injury, jugular bulb temperature measurements do not reflect true cerebral temperature. In fact, a two- to four-degree difference may exist [25-27]. In the severely brain-injured population, jugular vein temperature more accurately represents core body temperature instead of brain temperature. The difference becomes greater if the patient is febrile $[26,27]$. In a study by Rumana et al., the difference between jugular bulb and intraparenchymal brain temperature did not correlate with a decrease in global cerebral flow, injury severity, or type of injury [25]. Therefore, in the setting of brain injury, it is difficult to estimate actual brain temperature based on jugular bulb temperature alone.

Usually, commonly-used monitoring sites such as tympanic, bladder, esophageal, nasopharyngeal, and pulmonary artery are similar to brain temperature [16]. However, all 
Table 2. Indications for therapeutic hypothermia.

Adults who have ventricular fibrillation outside the hospital and do not have a "meaningful response to verbal commands" after regaining spontaneous circulation. ${ }^{19}$

Adults who are found to have pulseless electric activity or asystole outside the hospital and lack "meaningful response to verbal commands" after regaining spontaneous circulation. ${ }^{19}$

Adults who do not have "meaningful response to verbal commands" after regaining spontaneous circulation from cardiac arrest inside the hospital. ${ }^{19}$

Infants, at term or close to term, suffering from hypoxic-ischemic encephalopathy. ${ }^{24}$

consistently fail to match intraparenchymal temperature during induction of deep hypothermic cardiac arrest for cerebral aneurysm clipping procedures [16]. A solution to monitoring core temperature sites in lieu of cerebral temperature for non-severely brain injured patients, for whom large rapid changes in temperature during surgery are anticipated, is to monitor multiple sites to help identify outliers [16]. Since core body temperature provides a fair approximation of brain temperature [16], except in cases of severe brain injury [25-27], and rapid changes in body temperature [16], it may partially explain why hypothermia based on core temperature measurements provides neuroprotection.

\section{The importance of maintaining normothermia}

Hypothermia is defined by SCIP as a core body temperature less than $36^{\circ} \mathrm{C}$ [1]. Hyperthermia is defined as a core body temperature $>38.3^{\circ} \mathrm{C}$ [28]. Maintaining normothermia is necessary to prevent adverse effects, many relevant in the immediate postoperative period. Hypothermia causes shivering which in controlled settings can increase the metabolic rate up to 5 times the basal rate [29]. A higher rate of metabolism increases oxygen demand and causes a depletion of glycogen in the muscles [30] and high-energy phosphate stores [31]. Hypothermia is also associated with up to a $250 \%$ increase in minute ventilation [32], which may be detrimental in certain subsets of patients such as those with underlying lung disease. Increased metabolism, minute ventilation, and activation of the sympathetic system make avoidance of shivering necessary.

Hyperthermia is associated with patient discomfort, increased metabolic demand and increased cardiovascular stress [28]. There is a wide range of etiologies for fevers that can be categorized into syndromic, infectious or noninfectious [28,33-35]. The clinical option to treat fevers, specifically in neurologically intact patients, is reliant on etiology and clinical scenario. The availability of evidence-based guidelines is also lacking. Routine pharmaceutical and cooling treatments, in this population, are not recommended [28]. High temperatures are well tolerated in these patients with infectious causes and play a role in improved host immunological defense via decreasing microorganism growth and virulence [28].

In the critical care arena, aggressive treatment of fever is associated with an increased number of infections and mortality $[\mathbf{2 8}, \mathbf{3 4}]$. However, in patients with neurologic injury, pregnancy or the pediatric population, treatment of fevers may be beneficial [34-39]. The SCIP, and this review, focuses on perioperative warming and maintenance of normothermia, current applications of hypothermia, and the detrimental effects associated with hypothermia during the perioperative period. The vast topics of hyperthermia, its many etiologies, association with outcome and perioperative evidence-based guidelines has not been fully established and is not covered in detail in this review.

Hypothermia is associated with an increase in cardiac motility, most likely due to an increase in the amount of circulating catecholamines [3]. However, adverse cardiac events have been demonstrated only in patients with probable coexisting coronary atherosclerotic disease (CAD). The largest study to employ therapeutic hypothermia for surgical patients (IHAST), demonstrated no increase in the use of vasopressors, arrhythmias (other than sinus bradycardia), myocardial ischemia, or myocardial infarction in the group that underwent hypothermia $[\mathbf{4 0}, \mathbf{4 1}]$. The authors hypothesized this was due to the low incidence of coexisting CAD in their study group and further hypothesized that with adequate adrenergic blockade, even patients with a history of CAD would suffer a low incidence of cardiac events when cooled [41]. In a prospective study, Frank et al., demonstrated that patients who were allowed to become hypothermic did not differ from patients in which normothermia was maintained in the incidence of intraoperative ventricular tachycardia and myocardial ischemia [3]. However, patients who were not actively warmed had more cardiac events in the postoperative period [3]. This suggests that medications given for general anesthesia may be protective against the adverse effects of hypothermia on the heart [3]. Hence, until a pharmacological regimen is established to reduce cardiac morbidity, hypothermia for non-cardiac surgery should be avoided in patients with concomitant CAD unless the patient has another indication (Table 2).

Hypothermia in the post-operative period is thought to be a risk factor for surgical site infections (SSI) and delay wound healing $[4,20]$. In 1996, a randomized controlled trial reported that patients who were hypothermic at the end of surgery experienced a three-fold increase in the incidence of SSI [4]. The mean temperature in the hypothermic patients was $34.7^{\circ} \mathrm{C}$ compared to $36.6^{\circ} \mathrm{C}$ in the control patients [4]. Alternatively, in 1999, a retrospective study performed in the United States failed to identify any difference in the infection rate between hypothermic and normothermic patients [42]. On average, the lowest recorded temperature for the hypothermic and normotheric groups were $34.9^{\circ} \mathrm{C}$ and $35.9^{\circ} \mathrm{C}$, respectively [42]. Both differences in the two studies' designs and outcomes highlighted the complex nature of the relationship between hypothermia and SSIs.

In a recent retrospective study by Lehtinen et al., documentation of normothermia as a part of SCIP compliance 
Sappenfield et al. Journal of Anesthesiology and Clinical Science 2013,

http://www.hoajonline.com/journals/pdf/2049-9752-2-8.pdf

doi: $10.7243 / 2049-9752-2-8$

Table 3. Comorbidities impacted by non-therapeutic hypothermia.

\begin{tabular}{|c|c|}
\hline Patient Population & Deleterious Effects Associated with Hypothermia \\
\hline Sepsis & Increase in mortality ${ }^{28,51,52}$ \\
\hline CAD & $\begin{array}{l}\text { Increase incidence of vasopressor and/or inotropic } \\
\text { support }^{11} \\
\text { Increase occurrence of arrhythmia }^{3} \\
\text { Increase rate of angina or myocardial ischemia } \\
\text { Increase in mortality }^{31}\end{array}$ \\
\hline Trauma & $\begin{array}{l}\text { Increase mortality with hypothermia upon } \\
\text { admission }^{53-55} \\
\text { Increase mortality at } 24 \text { hours with slow rewarming }{ }^{56}\end{array}$ \\
\hline Pregnancy & $\begin{array}{l}\text { Shifts the oxygen delivery curve to the left } \\
\text { Decreases blood flow to the uterus }{ }^{57,58} \\
\text { May cause fetal bradycardia }\end{array}$ \\
\hline
\end{tabular}

failed to show a decrease in SSIs. In fact, more normothermic patients were found to develop SSIs, though this failed to reach statistical significance [43]. The authors concluded that SCIP standards should be reconsidered as a quality of care index in terms of prevention of SSIs [43]. Though it was suggested that the study had many weaknesses [44], the authors' intent was to show that a temperature above a single arbitrary value, in itself, does not improve outcome [45]. Recently, a large retrospective study found that documented adherence to postoperative normothermia in patients undergoing colorectal surgery had an adjusted odds ratio of $1.00(95 \% \mathrm{Cl}, 0.81$ to 1.23$)$ in reducing postoperative infections [46], a finding supported by others (adjusted odds ratio $1.02 ; 95 \% \mathrm{Cl}, 0.88$ to 1.18 ) [47]. However, there is an association with an increase in infectious complications involving hypothermia outside of the operating room [48-50]. Infectious complications are more likely associated with an increased duration of hypothermia [33].

Hypothermia causes coagulopathy, increasing the amount of surgical bleeding, and potentially leading to greater transfusion requirements [5]. Because of the heterogeneity of outcomes in multiple controlled trials, a meta-analysis of literature published before 2006 was performed [5]. It showed that a patient with a mean temperature of $35.6^{\circ} \mathrm{C}$ was likely to lose $16 \%$ more blood and was $22 \%$ more likely to receive a blood transfusion [5]. Therefore, based on the available evidence, hypothermia should be permitted only when clinically indicated for neuroprotection. Also, to be consistent with the American Heart Association's guidelines for the induction of hypothermia, "ongoing bleeding should be controlled before decreasing temperature "[19].

Hypothermia has been linked to additional adverse outcomes such as prolonged time to recovery from general anesthesia [6]. Drug effects are prolonged because of decreased metabolism and increased potency secondary to decreased body temperature [6]. For example, the clearance of midazolam and vecuronium is reduced approximately $11 \%$ for every degree Celsius drop in body temperature $[\mathbf{7 , 8}]$. Similarly, the metabolism of remifentanil is reduced by approximately $6 \%$ for every one degree Celsius drop in temperature [9]. Likewise, the metabolism of fentanyl and propofol are reduced $[12,13]$. A randomized controlled trial demonstrated that hypothermic patients (average intraoperative temperature $34.8^{\circ} \mathrm{C}$ ) took approximately 40 minutes longer to meet discharge criteria from the post anesthesia care unit compared to normothermic patients (average intraoperative temperature $36.7^{\circ} \mathrm{C}$ ) [6] When a temperature of $36^{\circ} \mathrm{C}$ was added to discharge criteria, discharge time was prolonged by 90 minutes [6].

Hypothermia has specifically been shown to be detrimental in patients with certain comorbidities as emphasized in Table 3. In septic patients, hypothermia is associated with a much higher incidence in mortality $[\mathbf{2 8 , 5 1 , 5 2 ]}$. This is likely because fever--a form of autologous hyperthermia-functions as an immunologic defense that combats infection [28,33-35]. Moreover, aggressive treatment of fever in the surgical critical care setting is associated with an increased number of infections and mortality [34].

Patients with CAD are not likely to tolerate the increased physiologic demands of hypothermia. Hypothermic patients with CAD have a higher incidence of vasopressor and/or inotropic support, arrhythmia, angina, myocardial ischemia, and mortality $[3,10,11]$. The proposed mechanism for an increase in morbidity and mortality is the increased adrenergic response to hypothermia, coupled with a decreased ability of the heart to respond to an increase in myocardial oxygen demand [41].

Hypothermia upon admission after trauma is associated with a three-fold increase in mortality in adults and more than double in pediatric patients [53-55]. Hypothermia at admission was also associated with severe functional impairment [53]. Trauma patients admitted to the intensive care unit with hypothermia who were aggressively rewarmed required less intravenous fluids, had a lower oxygen consumption on the second day after trauma, and overall had a lower rate of mortality in the first 24 hours [56]. Thus trauma patients should be rewarmed, especially in the setting of ongoing hemorrhage.

In isolated traumatic brain injury, hypothermia may have both positive and negative clinical effects. Hypothermia at the time of admission is associated with an increase in mortality [53]. However, the Brain Trauma Foundation et al., published guidelines in 2007 which gave level III recommendations for prophylactic hypothermia in severe traumatic brain injury [59]. Their meta-analysis failed to show a significant improvement in mortality; however patients treated with hypothermia had improved neurologic outcomes [59]. These recommendations were updated in 2008 after another systematic review showed that hypothermia may reduce mortality and improve neurologic outcomes [60]. The review found that the greatest benefit occurred when hypothermia was maintained for 48 hours; however hypothermia doubled the risk of pneumonia [60]. In 2011 the National Acute Brain Injury Study: Hypothermia II was published after being terminated early for futility [61]. No benefit could be attributed to early induced hypothermia in trauma patients [61]. However, the group containing intentionally hypothermic patients had a higher daily 
Sappenfield et al. Journal of Anesthesiology and Clinical Science 2013, http://www.hoajonline.com/journals/pdf/2049-9752-2-8.pdf

Table 4. Efficacy and disadvantages of different methods for maintaining normothermia.

\begin{tabular}{lll}
\hline Method & Efficacy & Disadvantages \\
\hline $\begin{array}{l}\text { Water circulating } \\
\text { gel-coated pads }\end{array}$ & Very $^{31}$ & Possible damage to skin $^{36}$ \\
\hline Prewarming & Very $^{71-75}$ & $\begin{array}{l}\text { Possible patient discomfort } \\
\text { Reduced efficacy with } \\
\text { prespiration }^{72}\end{array}$ \\
\hline Water garments & Very $^{76-78}$ & Possible burns $^{78}$ \\
\hline $\begin{array}{l}\text { Venous catheter-based } \\
\text { cooling systems }\end{array}$ & Very-Good $^{31,79}$ & Invasive \\
\hline $\begin{array}{l}\text { Forced air devices } \\
\text { Good }\end{array}$ & $\begin{array}{l}\text { Ineffective when wet } \\
\text { Possible burns when warming }^{82} \\
\text { Possible shivering when cooling }\end{array}$ \\
\hline $\begin{array}{l}\text { Warmed or cold } \\
\text { intravenous fluids }\end{array}$ & Minimal $^{20,36}$ & $\begin{array}{l}\text { Possible hemodilution } \\
\text { Possible coagulation } \\
\text { derangements }\end{array}$ \\
\hline $\begin{array}{l}\text { Heated humidification } \\
\text { of gases }\end{array}$ & Minimal $^{69,70}$ & Minimal to none \\
\hline $\begin{array}{l}\text { Passive insulation } \\
\text { (warming or cooling) }\end{array}$ & Minimal $^{80}$ & Possible shivering when cooling \\
\hline
\end{tabular}

therapeutic intervention score in the intensive care unit for increased intracranial pressures and double the rate of prehospital hypoxia [61]. The same authors performed a combined analysis of their randomized prospective multi-site studies and found that induction of hypothermia in patients with traumatic brain injury who had a craniotomy for hematoma halved the incidence of a "poor outcome" [61-63]. Poor outcome was defined as severe disability, vegetative state, and death using the Glasgow Outcome Scale [63]. The study did not find a significant increase in the incidence of rehemorrhaging after hematoma evacuation in the hypothermic group [63] Currently the Eurotherm3235Trial is being performed in Europe and is hoping to recruit 1800 patients by January 2013 with traumatic brain injury causing elevated intracranial pressure [64]. It may become the largest study to date to examine traumatic brain injury and hypothermia.

Pregnant patients are uniquely affected by hypothermia. There are multiple case reports of induction of hypothermia in the first, second, and third trimester with later successful delivery of a healthy infant $[\mathbf{5 7}, \mathbf{5 8}, \mathbf{6 5}]$. However, no controlled trials have been conducted in this patient population. Hypothermia shifts the oxygen delivery curve to the left, decreases blood flow to the uterus $[\mathbf{5 7 , 5 8}]$, and may cause fetal bradycardia [58]. Therefore, it is prudent to strictly follow the SCIP measurement in patients with pregnancy, trauma, $C A D$, and sepsis.

\section{SCIP measurement and maintenance of normothermia} The SCIP measurement describes a limited number of techniques for maintaining normothermia. Forced air warming, or water garments, as well as appropriate passive insulation and an increased ambient temperature of the operating room are recommended. With forced air warming devices, there has been some concern that the devices may increase the spread of bacteria in the operating room however; this does not seem to increase the incidence of surgical site infections [66-68] The SCIP measurement also suggests warming intravenous (IV) fluids [1], though the use of warmed IV fluids as a sole intervention to treat or prevent hypothermia has been shown to be ineffective [20].

Various additional methods for preventing and treating hypothermia are commercially available, but not endorsed by SCIP. Heated humidification of ventilator gases and passive heat and moisture exchangers do not significantly alter changes in patient body temperature $[69,70]$. One effective strategy for maintaining normothermia involves warming the patient preoperatively. This strategy has been shown to significantly attenuate, and prevent, hypothermia from redistribution of blood from the patient's core to periphery while under general anesthesia [71-75]. Recently, prewarming the patient for as little as 10 to 20 minutes has been shown as effective at reducing perioperative hypothermia and postoperative shivering [75]. Disadvantages with preoperative warming include reduced efficacy with sweating and patient discomfort $\left[\mathbf{7 2 , 7 5 ]}\right.$. The Artic Sun ${ }^{\mathrm{TM}}$ Temperature Management System (Medivance Inc., Louisville, CO) has been shown "to be more effective for rewarming patients after off-pump coronary artery bypass than conventional warming methods." [31]. Additionally, the heatexchanger on the CPB machine, while obviously impractical for the majority of surgical cases, is highly effective at adjusting body temperature [36]. A summary of the aforementioned techniques, their efficacy, and weaknesses is listed in Table 4.

In patients with neurologic injury [34,36-38], who are pregnant [37], or under the age of six [34,35,39], it may be beneficial to treat or prevent hyperthermia. When controllingfever, the goal is to eliminate the cause. All other interventions should either be used in conjunction or until the source of the fever can be identified. Antipyretics may be used although they are rarely efficacious $[34,36,38,84]$, especially if thermoregulatory centers have been damaged from a neurologic insult [38]. Cooling with a forced air device in the intensive care unit has been shown to be ineffective [38], however failure was attributed to intolerance from the patient, shivering, and vasoconstriction which all can be avoided with general anesthesia. Other devices that have shown good efficacy in lowering body temperature include; water circulating gel-coated pads, water garments, intravascular devices, and infusion of cold intravenous fluids [7,31,34,36,79,83,85-87].

\section{Indications for intraoperative hypothermia}

An accepted exclusion to normothermia within the SCIP measurement is intentional hypothermia [1]. Moderate hypothermia is the only intervention shown to consistently provide neuroprotection in humans [88]. Although there is some suggestion of benefit from normoglycemia and intravenous administration of barbiturates and lidocaine, none of these interventions have been shown to provide 
any benefit during ischemia to the human brain [88]. Mild hyperthermia, hyperventilation, hyperbaric oxygen, propofol, etomidate, nitrous oxide, isoflurane, sevoflurane, desflurane, ketamine, and glucocorticoids have not been shown to provide neuroprotection [88].

Theoretically, patients undergoing surgery who have a neurologic insult should receive the greatest benefit from hypothermia. In addition to the suppression of thermoregulatory responses that occurs under general anesthesia, patients can be cooled rapidly before, or shortly after, a neurologic insult. This would maximize the neuroprotective effects of hypothermia when the brain tissue is most vulnerable. Nonetheless, hypothermia has only been proven to be clinically beneficial in patients undergoing cardiac arrest outside the hospital, who have a rapid return of spontaneous circulation $[31,48,89]$ or neonatal patients suffering from hypoxic-ischemic encephalopathy [31,90-93]. Outside of surgical procedures requiring deep hypothermic circulatory arrest, the current indications for therapeutic hypothermia are described in Table 2. This is relevant to anesthesiologists because some of these patients present for interventions to reestablish coronary perfusion post arrest. It is also unclear what should be done for the patient who arrests in the operating room. The current guidelines further state that "active rewarming should be avoided in comatose patients who spontaneously develop a mild degree of hypothermia" during two days post arrest [19]. There is a paucity of evidence regarding active warming in patients post arrest intraoperatively.

Selected patients with cardiac disease may potentially benefit from therapeutic hypothermia [94-96], although the literature supporting beneficial outcomes is inconclusive and currently not an accepted indication. Conflicting results in the literature regarding hypothermia and CPB might be explained by confounding factors such as intraoperative cerebral hyperthermia, perioperative hyperglycemia, rapid rewarming, and postoperative hyperthermia [97]. In a thorough review, Grigore et al., recommended that patients, with a low risk of cognitive or neurologic dysfunction, have their temperature fall to $34^{\circ} \mathrm{C}-35^{\circ} \mathrm{C}$, followed by slow rewarming to $37^{\circ} \mathrm{C}$ [97]. For high-risk patients with a long $\mathrm{CPB}$ time, hypothermia may be actively induced $\left(28^{\circ} \mathrm{C}-30^{\circ} \mathrm{C}\right)$ followed by slow rewarming to $37^{\circ} \mathrm{C}$ [97]. For high-risk patients with a short CPB time, hypothermia may be induced to $32^{\circ} \mathrm{C}$, followed by slow surface warming postoperatively in the intensive care unit [97].

The SCIP standard allows for hypothermia; however, the standard does not address efficacious methods for lowering body temperature. Packing the patient in ice or using a traditional cooling blanket is inadequate, and these methods can cause significant skin damage $[31,34,84,98,99]$. Catheter-based heat exchange devices $[34,79,85,86]$, advanced surface cooling devices $[34,87]$, and intravenous infusions of cooled liquids $[7,31,83]$, have all been found to be highly effective at reducing body temperature. Yet, each of these methods has advantages and disadvantages (Table 4).

Catheter-based cooling systems are more effective than ice and cooling blankets, but carry risks associated with placement of a central venous catheter $[31,79]$. Water circulating gelcoated pads, such as the Artic Sun ${ }^{\mathrm{TM}}$ Temperature Management System (Medivance Inc., Louisville, CO), have also been shown to be effective [87]. However, this device poses a risk of damage to the skin [36]. Catheter-based devices may be better able to maintain a stable temperature than water circulating gelcoated pads [31,79]. Another cost-effective method for cooling involves infusion of refrigerated IV crystalloids. However, this technique may cause hemodilution, coagulation derangements [83], and is ineffective at maintaining temperature in a narrow range [36]. The reader is referred to an excellent review of techniques for inducing hypothermia by Polderman, et al., [36].

Adverse effects from hypothermia should be minimized. Shivering can be prevented in conscious, moderately hypothermic, spontaneously breathing patients with a combination of meperidine and buspirone $[85,99,100]$. Alternately, endovascular cooling (e.g. use of a venous catheter-based temperature management system) with concomitant surface warming (e.g. application of a forced warm air blanket) can prevent shivering by modifying the input to the thermoregulatory centers, allowing for a greater degree of hypothermia [99]. While hypothermic, patients should be monitored for changes in blood pressure, arrhythmias, and other cardiac events $[3,10,11]$. When implementing devices for altering temperature, it is recommended to monitor for complications associated with each strategy such as line infections, venous thrombosis, and skin injury [101].

\section{Conclusion}

The SCIP guidelines were created to improve patient outcomes. Regardless of their efficacy, or relevance to temperature management practices in the operating room, anesthesiologists should strive to integrate the physiologic basis of these guidelines into an evidencebased practice designed to optimize patient outcomes. Core body temperature should be measured with a modality of monitoring that is least affected by operative technique or patient condition. Hypothermia should be induced only when appropriate for neuroprotection because of the increased associated amount of hemorrhaging, amount of transfusions, time to recover from anesthesia, and morbidity in patients with sepsis, CAD, and trauma. Methods for manipulating body temperature should be implemented when indicated. Due to the importance of body temperature control in patient outcomes, it will likely remain a priority throughout the perioperative period as the evolution of best practice in anesthesiology continues to occur.

\section{Competing interests}

The authors declare that they have no competing interests.

Authors' contributions

JS carried out the majority of the literature review, wrote the original draft of the manuscript, and made multiple revisions 
the manuscript. $\mathrm{CH}$ helped with the literature review, directed the structure of the manuscript, and made multiple revisions to the manuscript. SG helped with the literature review, helped with interpretation of other studies statistical analysis, directed the structure of the manuscript, and made multiple revisions to the manuscript. All authors read and approved the final manuscript.

Acknowledgements

The authors would like to thank Dr. Andrew Malinow

for his assistance in editing this manuscript.

\section{Publication history}

Received: 12-Dec-2012 Revised: 17-Jan-2013

Accepted: 23-Jan-2013 Published: 01-Feb-2013

\section{References}

1. National Quality Measures Clearinghouse. Anesthesiology and critical care: percentage of patients, regardless of age, undergoing surgical or therapeutic procedures under general or neuraxial anesthesia of 60 minutes duration or longer for whom either active warming was used intraoperatively for the purpose of maintaining normothermia, $O R$ at least one body temperature equal to or greater than 36 degrees Centigrade (or $\mathbf{9 6 . 8}$ degrees Fahrenheit) was recorded within $\mathbf{3 0}$ minutes immediately before or the 15 minutes immediately after anesthesia end time. 2007. | Website

2. Sessler D I: A proposal for new temperature monitoring and thermal management guidelines. Anesthesiology 1998, 89:1298-300. | Article | PubMed

3. Frank S M, Fleisher L A, Breslow M J, Higgins M S, Olson K F, Kelly S and Beattie $C$ : Perioperative maintenance of normothermia reduces the incidence of morbid cardiac events. A randomized clinical trial. JAMA 1997, 277:1127-34. | Article | PubMed

4. Kurz A, Sessler D I and Lenhardt R: Perioperative normothermia to reduce the incidence of surgical-wound infection and shorten hospitalization. Study of Wound Infection and Temperature Group. $N$ Engl J Med 1996, 334:1209-15. | Article | PubMed

5. Rajagopalan S, Mascha E, Na J and Sessler D I: The effects of mild perioperative hypothermia on blood loss and transfusion requirement. Anesthesiology 2008, 108:71-7. | Article | PubMed

6. Lenhardt R, Marker E, Goll V, Tschernich $H$, Kurz A, Sessler D I, Narzt E and Lackner F: Mild intraoperative hypothermia rolongs postanesthetic recovery. Anesthesiology 1997, 87:1318-23. | Article | PubMed

7. Hostler D, Zhou J, Tortorici M A, Bies R R, Rittenberger J C, Empey P E, Kochanek P M, Callaway C W and Poloyac S M: Mild hypothermia alters midazolam pharmacokinetics in normal healthy volunteers. Drug Metab Dispos 2010, 38:781-8. | Article I PubMed Abstract I PubMed Full Text

8. Caldwell J E, Heier T, Wright P M, Lin S, McCarthy G, Szenohradszky J, Sharma M L, Hing J P, Schroeder M and Sessler D I: Temperaturedependent pharmacokinetics and pharmacodynamics of vecuronium. Anesthesiology 2000, 92:84-93. | Article | PubMed

9. Michelsen L G, Holford N H, Lu W, Hoke J F, Hug C C and Bailey J M: The pharmacokinetics of remifentanil in patients undergoing coronary artery bypass grafting with cardiopulmonary bypass. Anesth Analg 2001, 93:1100-5. | Article | PubMed

10. Frank S M, Beattie C, Christopherson R, Norris E J, Perler B A, Williams $\mathrm{G} \mathrm{M}$ and Gottlieb S O: Unintentional hypothermia is associated with postoperative myocardial ischemia. The Perioperative Ischemia Randomized Anesthesia Trial Study Group. Anesthesiology 1993, 78:468-76. | Article | PubMed

11. Bush H L, Jr., Hydo L J, Fischer E, Fantini G A, Silane M F and Barie $P$ $S$ : Hypothermia during elective abdominal aortic aneurysm repair: the high price of avoidable morbidity. J Vasc Surg 1995, 21:392-400; discussion 400-2. I Article I PubMed

12. Fritz H G, Holzmayr M, Walter B, Moeritz K U, Lupp A and Bauer R: The effect of mild hypothermia on plasma fentanyl concentration and biotransformation in juvenile pigs. Anesth Analg 2005, 100:996-1002. | Article | PubMed

13. Leslie K, Sessler D I, Bjorksten A R and Moayeri A: Mild hypothermia alters propofol pharmacokinetics and increases the duration of action of atracurium. Anesth Analg 1995, 80:1007-14. | Article | PubMed
14. Winkler M, Akca O, Birkenberg B, Hetz H, Scheck T, Arkilic C F, Kabon B, Marker E, Grubl A, Czepan R, Greher M, Goll V, Gottsauner-Wolf F, Kurz $A$ and Sessler D I: Aggressive warming reduces blood loss during hip arthroplasty. Anesth Analg 2000, 91:978-84. | Article I PubMed

15. Sessler D I: Temperature monitoring and perioperative thermoregulation. Anesthesiology 2008, 109:318-38. | Article | PubMed Abstract | PubMed Full Text

16. Stone J G, Young W L, Smith C R, Solomon R A, Wald A, Ostapkovich $\mathrm{N}$ and Shrebnick D B: Do standard monitoring sites reflect true brain temperature when profound hypothermia is rapidly induced and reversed? nesthesiology 1995, 82:344-51. I Article | PubMed

17. Akata T, Setoguchi H, Shirozu K and Yoshino J: Reliability of temperatures measured at standard monitoring sites as an index of brain temperature during deep hypothermic cardiopulmonary bypass conducted for thoracic aortic reconstruction. J Thorac Cardiovasc Surg 2007, 133:1559-65. | Article | PubMed

18. Nelson E J and Grissom T E: Continuous gastric suctioning decreases measured esophageal temperature during general anesthesia. J Clin Monit 1996, 12:429-32. I Article I PubMed

19. Peberdy M A, Callaway C W, Neumar R W, Geocadin R G, Zimmerman J L, Donnino M, Gabrielli A, Silvers S M, Zaritsky A L, Merchant R, Vanden Hoek T L and Kronick S L: Part 9: post-cardiac arrest care: 2010 American Heart Association Guidelines for Cardiopulmonary Resuscitation and Emergency Cardiovascular Care. Circulation 2010, 122:S768-86. | Article | PubMed

20. Insler S R and Sessler D I: Perioperative thermoregulation and temperature monitoring. Anesthesiol Clin 2006, 24:823-37. | PDF | PubMed

21. Muravchick S: Deep body thermometry during general anesthesia. Anesthesiology 1983, 58:271-5. | Article | PubMed

22. Evans D C, Doraiswamy V A, Prosciak M P, Silviera $M$, Seamon $M$ J, Rodriguez Funes V, Cipolla J, Wang C F, Kavuturu S, Torigian D A, Cook C H, Lindsey D E, Steinberg S M and Stawicki S P: Complications associated with pulmonary artery catheters: a comprehensive clinical review. Scand J Surg 2009, 98:199-208. I PDF I PubMed

23. Hadian M and Pinsky M R: Evidence-based review of the use of the pulmonary artery catheter: impact data and complications. Crit Care 2006, 10 Suppl 3:S8. | Article | PubMed Abstract | PubMed Full Text

24. Perlman J M, Wyllie J, Kattwinkel J, Atkins D L, Chameides L, Goldsmith J P, Guinsburg R, Hazinski M F, Morley C, Richmond S, Simon W M, Singhal N, Szyld E, Tamura M and Velaphi S: Part 11: Neonatal resuscitation: 2010 International Consensus on Cardiopulmonary Resuscitation and Emergency Cardiovascular Care Science With Treatment Recommendations. Circulation 2010, 122:S516-38. | Article | PubMed

25. Rumana C S, Gopinath S P, Uzura M, Valadka A B and Robertson C S: Brain temperature exceeds systemic temperature in head-injured patients. CritCare Med 1998, 26:562-7. | Article | PubMed

26. Henker R A, Brown S D and Marion D W: Comparison of brain temperature with bladder and rectal temperatures in adults with severe head injury. Neurosurgery 1998, 42:1071-5. | Article | PubMed

27. Rossi S, Zanier E R, Mauri I, Columbo A and Stocchetti N: Brain temperature, body core temperature, and intracranial pressure in acute cerebral damage. J Neurol Neurosurg Psychiatry 2001, 71:44854. | Article | PubMed Abstract | PubMed Full Text

28. Laupland K B: Fever in the critically ill medical patient. Crit Care Med 2009, 37:S273-8. | Article | PubMed

29. Eyolfson D A, Tikuisis P, Xu X, Weseen G and Giesbrecht G G: Masurement and prediction of peak shivering intensity in humans. Eur J Appl Physiol 2001, 84:100-6. | Article | PubMed

30. Haman F: Shivering in the cold: from mechanisms of fuel selection to survival. J Appl Physiol 2006, 100:1702-8. | Article | PubMed

31. Marion $D$ and Bullock $M R$ : Current and future role of therapeutic hypothermia. J Neurotrauma 2009, 26:455-67. | Article | PubMed

32. Horvath S M, Spurr G B, Hutt B K and Hamilton L H: Metabolic cost of shivering. J Appl Physiol 1956, 8:595-602. | Article | PubMed

33. Badjatia N: Fever control in the neuro-ICU: why, who, and when? Curr Opin Crit Care 2009, 15:79-82. | Article | PubMed

34. Aiyagari $\mathrm{V}$ and Diringer $\mathrm{M} \mathrm{N}$ : Fever control and its impact on outcomes: what is the evidence? J Neurol Sci 2007, 261:39-46. | Article I PubMed 
35. Mackowiak P A: Physiological rationale for suppression of fever. Clin Infect Dis 2000, 31 Suppl 5:S185-9. | Article | PubMed

36. Polderman $\mathrm{K} \mathrm{H}$ : Keeping a cool head: How to induce and maintain hypothermia. Crit Care Med 2004, 32:2558-60. | Article I PubMed

37. Roth J V: Some unanswered questions about temperature management. Anesth Analg 2009, 109:1695-9. I Article I PubMed

38. Mayer S, Commichau C, Scarmeas N, Presciutti M, Bates J and Copeland $D$ : Clinical trial of an air-circulating cooling blanket for fever control in critically ill neurologic patients. Neurology 2001, 56:292-8. | Article | PubMed

39. Sugai K: Current management of febrile seizures in Japan: an overview. Brain Dev 2010, 32:64-70. | Article | PubMed

40. Todd M M, Hindman B J, Clarke W R and Torner J C: Mild intraoperative hypothermia during surgery for intracranial aneurysm. N Engl J Med 2005, 352:135-45. | Article | PubMed

41. Nguyen H P, Zaroff J G, Bayman E O, Gelb A W, Todd M M and Hindman B J: Perioperative hypothermia $\left(33^{\circ} \mathrm{C}\right)$ does not increase the occurrence of cardiovascular events in patients undergoing cerebral aneurysm surgery: findings from the Intraoperative Hypothermia for Aneurysm Surgery Trial. Anesthesiology 2010, 113:327-42. | Article | PubMed Abstract | PubMed Full Text

42. Barone J E, Tucker J B, Cecere J, Yoon M Y, Reinhard E, Blabey R G, Jr. and Lowenfels A B: Hypothermia does not result in more complications after colon surgery. Am Surg 1999, 65:356-9. I Article | PubMed

43. Lehtinen S J, Onicescu G, Kuhn K M, Cole D J and Esnaola N F: Normothermia to prevent surgical site infections after gastrointestinal surgery: holy grail or false idol? Ann Surg 2010, 252:696-704. I Article | PubMed Abstract | PubMed Full Text

44. Sessler D I: Holy grail or false idol-and how to tell the difference. Ann Surg 2011, 254:673-4. I Article | PubMed

45. Esnaola NF: Holy grail or false idol-and how to tell the difference. Ann Surg 2011, 254:674-5. I Article

46. Stulberg J J, Delaney C P, Neuhauser D V, Aron D C, Fu P and Koroukian $S \mathrm{M}$ : Adherence to surgical care improvement project measures and the association with postoperative infections. JAMA 2010, 303:247985. I Article I PubMed

47. Hawn M T, Vick C C, Richman J, Holman W, Deierhoi R J, Graham L A, Henderson W G and Itani K M: Surgical site infection prevention: time to move beyond the surgical care improvement program. Ann Surg 2011, 254:494-9; discussion 499-501. | Article | PubMed

48. Hypothermia after Cardiac Arrest Study Group. Mild therapeutic hypothermia to improve the neurologic outcome after cardiac arrest. N Engl J Med 2002, 346:549-56. I Article I PubMed

49. Shiozaki T, Hayakata T, Taneda M, Nakajima Y, Hashiguchi N, Fujimi S, Nakamori Y, Tanaka H, Shimazu T and Sugimoto H: A multicenter prospective randomized controlled trial of the efficacy of mild hypothermia for severely head injured patients with low intracranial pressure. Mild Hypothermia Study Group in Japan. J Neurosurg 2001, 94:50-4. I Article I PubMed

50. Clifton G L, Allen S, Barrodale P, Plenger P, Berry J, Koch S, Fletcher J, Hayes R L and Choi S C: A phase II study of moderate hypothermia in severe brain injury. J Neurotrauma 1993, 10:263-71; discussion 273. | Article | PubMed

51. Peres Bota D, Lopes Ferreira F, Melot C and Vincent J L: Body temperature alterations in the critically ill. Intensive Care Med 2004, 30:811-6. | Article | PubMed

52. Arons M M, Wheeler A P, Bernard G R, Christman B W, Russell J A, Schein R, Summer W R, Steinberg K P, Fulkerson W, Wright P, Dupont W $D$ and Swindell $B$ B: Effects of ibuprofen on the physiology and survival of hypothermic sepsis. Ibuprofen in Sepsis Study Group. Crit Care Med 1999, 27:699-707. | Article | PubMed

53. Wang $\mathrm{H} \mathrm{E}$, Callaway $\mathrm{C}$ W, Peitzman A B and Tisherman S A: Admission hypothermia and outcome after major trauma. Crit Care Med 2005, 33:1296-301. | Article | PubMed

54. Sundberg J, Estrada C, Jenkins C, Ray J and Abramo T: Hypothermia is associated with poor outcome in pediatric trauma patients. $\mathrm{Am} \mathrm{J}$ Emerg Med 2011, 29:1019-22. | Article | PubMed

55. Waibel B H, Durham C A, Newell M A, Schlitzkus L L, Sagraves S G and Rotondo M F: Impact of hypothermia in the rural, pediatric trauma patient. Pediatr Crit Care Med 2010, 11:199-204. | Article | PubMed

56. Gentilello L M, Jurkovich G J, Stark M S, Hassantash S A and O'Keefe
$\mathrm{G} E$ : Is hypothermia in the victim of major trauma protective or harmful? A randomized, prospective study. Ann Surg 1997, 226:43947; discussion 447-9. | Article | PubMed Abstract | PubMed Full Text

57. Kamrin R P and Masland W: Intracranial Surgery under Hypothermia during Pregnancy. Arch Neurol 1965, 13:70-6. | Article | PubMed

58. Hess O W and Davis C D: Electronic Evaluation of the Fetal and Maternal Heart Rate during Hypothermia in a Pregnant Woman. Am J Obstet Gynecol 1964, 89:801-7. I Article I PubMed

59. Bratton S L, Chestnut R M, Ghajar J, McConnell Hammond F F, Harris O A, Hartl R, Manley G T, Nemecek A, Newell D W, Rosenthal G, Schouten J, Shutter L, Timmons S D, Ullman J S, Videtta W, Wilberger J E and Wright D W: Guidelines for the management of severe traumatic brain injury. III. Prophylactic hypothermia. J Neurotrauma 2007, 24 Suppl 1:S21-5. | Article | PubMed

60. Peterson K, Carson S and Carney N: Hypothermia treatment for traumatic brain injury: a systematic review and meta-analysis. $J$ Neurotrauma 2008, 25:62-71. | Article | PubMed

61. Clifton G L, Valadka A, Zygun D, Coffey C S, Drever P, Fourwinds S, Janis L S, Wilde E, Taylor P, Harshman K, Conley A, Puccio A, Levin H S, McCauley S R, Bucholz R D, Smith K R, Schmidt J H, Scott J N, Yonas $\mathrm{H}$ and Okonkwo D O: Very early hypothermia induction in patients with severe brain injury (the National Acute Brain Injury Study: Hypothermia II): a randomised trial. Lancet Neurol 2011, 10:131-9. | Article I PubMed

62. Clifton G L, Miller E R, Choi S C, Levin H S, McCauley S, Smith K R, Jr., Muizelaar J P, Wagner F C, Jr., Marion D W, Luerssen T G, Chesnut R $M$ and Schwartz M: Lack of effect of induction of hypothermia after acute brain injury. N Engl J Med 2001, 344:556-63. I Article I PubMed

63. Clifton G L, Coffey C S, Fourwinds S, Zygun D, Valadka A, Smith K R, Jr., Frisby M L, Bucholz R D, Wilde E A, Levin H S and Okonkwo D O: Early induction of hypothermia for evacuated intracranial hematomas: a post hoc analysis of two clinical trials. J Neurosurg 2012, 117:714-20. | Article | PubMed

64. Andrews P J, Sinclair H L, Battison C G, Polderman K H, Citerio G, Mascia L, Harris B A, Murray G D, Stocchetti N, Menon D K, Shakur H and De Backer D: European society of intensive care medicine study of therapeutic hypothermia (32-35 degrees C) for intracranial pressure reduction after traumatic brain injury (the Eurotherm3235Trial). Trials 2011, 12:8. | Article | PubMed Abstract | PubMed Full Text

65. Burstein P N, Perese D M and Kaminski C J: Ruptured Berry Aneurysm during Pregnancy: Successful Repair under Hypothermia. Obstet Gynecol 1964, 24:463-7. | Article | PubMed

66. Huang J K, Shah E F, Vinodkumar N, Hegarty M A and Greatorex R $A$ : The Bair Hugger patient warming system in prolonged vascular surgery: an infection risk? Crit Care 2003, 7:R13-6. | Article | PubMed Abstract | PubMed Full Text

67. Tumia N and Ashcroft G P: Convection warmers--a possible source of contamination in laminar airflow operating theatres? J Hosp Infect 2002, 52:171-4. | Article | PubMed

68. Moretti B, Larocca A M, Napoli C, Martinelli D, Paolillo L, Cassano M, Notarnicola A, Moretti $L$ and Pesce $V$ : Active warming systems to maintain perioperative normothermia in hip replacement surgery: a therapeutic aid or a vector of infection? J Hosp Infect 2009, 73:58-63. | Article | PubMed

69. Goldberg M E, Epstein R, Rosenblum F, Larijani G E, Marr A, Lessin J, Torjman $M$ and Seltzer J: Do heated humidifiers and heat and moisture exchangers prevent temperature drop during lower abdominal surgery? J Clin Anesth 1992, 4:16-20. | Article | PubMed

70. Hynson J M and Sessler D I: Intraoperative warming therapies: a comparison of three devices. J Clin Anesth 1992, 4:194-9. | Article | PubMed

71. Andrzejowski J, Hoyle J, Eapen G and Turnbull D: Effect of prewarming on post-induction core temperature and the incidence of inadvertent perioperative hypothermia in patients undergoing general anaesthesia. Br J Anaesth 2008, 101:627-31. | Article | PubMed

72. Sessler D I, Schroeder M, Merrifield B, Matsukawa T and Cheng C: Optimal duration and temperature of prewarming. Anesthesiology 1995, 82:674-81. I Article I PubMed

73. Just B, Trevien V, Delva E and Lienhart A: Prevention of intraoperative hypothermia by preoperative skin-surface warming. Anesthesiology 1993, 79:214-8. | Article | PubMed

74. Kim J Y, Shinn H, Oh Y J, Hong Y W, Kwak H J and Kwak Y L: The effect 
of skin surface warming during anesthesia preparation on preventing redistribution hypothermia in the early operative period of off-pump coronary artery bypass surgery. Eur J Cardiothorac Surg 2006, 29:3437. | Article | PubMed

75. Horn E P, Bein B, Bohm R, Steinfath M, Sahili N and Hocker J: The effect of short time periods of pre-operative warming in the prevention of peri-operative hypothermia. Anaesthesia 2012, 67:612-7. | Article | PubMed

76. Janicki P K, Stoica C, Chapman W C, Wright J K, Walker G, Pai R, Walia $A$, Pretorius $M$ and Pinson $C W$ : Water warming garment versus forced air warming system in prevention of intraoperative hypothermia during liver transplantation: a randomized controlled trial [ISRCTN32154832]. BMC Anesthesiol 2002, 2:7. | Article | PubMed Abstract | PubMed Full Text

77. Janicki P K, Higgins M S, Janssen J, Johnson R F and Beattie C: Comparison of two different temperature maintenance strategies during open abdominal surgery: upper body forced-air warming versus whole body water garment. Anesthesiology 2001, 95:868-74. | Article | PubMed

78. Wadhwa A, Komatsu R, Orhan-Sungur M, Barnes P, In J, Sessler D I and Lenhardt R: New circulating-water devices warm more quickly than forced-air in volunteers. Anesth Analg 2007, 105:1681-7. | Article | PubMed

79. Diringer $\mathrm{M} N$ : Treatment of fever in the neurologic intensive care unit with a catheter-based heat exchange system. Crit Care Med 2004, 32:559-64. | Article | PubMed

80. Mahoney $C B$ and Odom J: Maintaining intraoperative normothermia: a meta-analysis of outcomes with costs. AANA J 1999, 67:155-63. | PDF I PubMed

81. Lin E P, Smith K and Valley R D: Wet forced-air warming blankets are ineffective at maintaining normothermia. aediatr Anaesth 2008, 18:642-4. | Article | PubMed

82. Azzam F J and Krock J L: Thermal burns in two infants associated with a forced air warming system. Anesth Analg 1995, 81:661. | Article | PubMed

83. Spiel A O, Kliegel A, Janata A, Uray T, Mayr F B, Laggner A N, Jilma B and Sterz $\mathrm{F}$ : Hemostasis in cardiac arrest patients treated with mild hypothermia initiated by cold fluids. Resuscitation 2009, 80:762-5. I Article | PubMed

84. Axelrod $\mathrm{YK}$ and Diringer $\mathrm{M} \mathrm{N}$ : Temperature management in acute neurologic disorders. Neurol Clin 2008, 26:585-603. | Article | PubMed

85. Dixon S R, Whitbourn R J, Dae M W, Grube E, Sherman W, Schaer G L, Jenkins J S, Baim D S, Gibbons R J, Kuntz R E, Popma J J, Nguyen T T and O'Neill W W: Induction of mild systemic hypothermia with endovascular cooling during primary percutaneous coronary intervention for acute myocardial infarction. J Am Coll Cardiol 2002, 40:1928-34. | Article | PubMed

86. Schmutzhard E, Engelhardt K, Beer R, Brossner G, Pfausler B, Spiss $\mathrm{H}$, Unterberger I and Kampfl A: Safety and efficacy of a novel intravascular cooling device to control body temperature in neurologic intensive care patients: a prospective pilot study. Crit Care Med 2002, 30:2481-8. | Article | PubMed

87. Mayer S A, Kowalski R G, Presciutti M, Ostapkovich N D, McGann E, Fitzsimmons B F, Yavagal D R, Du Y E, Naidech A M, Janjua N A, Claassen J, Kreiter K T, Parra A and Commichau C: Clinical trial of a novel surface cooling system for fever control in neurocritical care patients. Crit Care Med 2004, 32:2508-15. | Article | PubMed

88. Fukuda S and Warner D S: Cerebral protection. Br J Anaesth 2007, 99:10-7. | Article | PubMed

89. Bernard S A, Gray T W, Buist M D, Jones B M, Silvester W, Gutteridge $G$ and Smith K: Treatment of comatose survivors of out-of-hospital cardiac arrest with induced hypothermia. N Engl J Med 2002, 346:55763. | Article | PubMed

90. Shankaran S, Laptook A R, Ehrenkranz R A, Tyson J E, McDonald S A, Donovan E F, Fanaroff A A, Poole W K, Wright L L, Higgins R D, Finer N N, Carlo W A, Duara S, Oh W, Cotten C M, Stevenson D K, Stoll B J, Lemons J A, Guillet R and Jobe A H: Whole-body hypothermia for neonates with hypoxic-ischemic encephalopathy. N Engl J Med 2005, 353:1574-84. | Article | PubMed

91. Eicher D J, Wagner C L, Katikaneni L P, Hulsey T C, Bass W T, Kaufman D A, Horgan M J, Languani S, Bhatia J J, Givelichian L M, Sankaran K and Yager I Y: Moderate hypothermia in neonatal encephalopathy: efficacy outcomes. Pediatr Neurol 2005, 32:11-7. | Article | PubMed
92. Wyatt J S, Gluckman P D, Liu P Y, Azzopardi D, Ballard R, Edwards A D, Ferriero D M, Polin R A, Robertson C M, Thoresen M, Whitelaw A and Gunn A J: Determinants of outcomes after head cooling for neonatal encephalopathy. Pediatrics 2007, 119:912-21. | Article | PubMed

93. Gunn A J, Wyatt J S, Whitelaw A, Barks J, Azzopardi D, Ballard R, Edwards A D, Ferriero D M, Gluckman P D, Polin R A, Robertson C M and Thoresen $\mathrm{M}$ : Therapeutic hypothermia changes the prognostic value of clinical evaluation of neonatal encephalopathy. J Pediatr 2008, 152:55-8, 58 e1. | Article | PubMed

94. Martin T D, Craver J M, Gott J P, Weintraub W S, Ramsay J, Mora C T and Guyton R A: Prospective, randomized trial of retrograde warm blood cardioplegia: myocardial benefit and neurologic threat. Ann Thorac Surg 1994, 57:298-302; discussion 302-4. | PDF | PubMed

95. Regragui I, Birdi I, Izzat M B, Black A M, Lopatatzidis A, Day C J, Gardner $F$, Bryan A J and Angelini G D: The effects of cardiopulmonary bypass temperature on neuropsychologic outcome after coronary artery operations: a prospective randomized trial. J Thorac Cardiovasc Surg 1996, 112:1036-45. | Article | PubMed

96. Nathan H J, Wells G A, Munson J L and Wozny D: Neuroprotective effect of mild hypothermia in patients undergoing coronary artery surgery with cardiopulmonary bypass: a randomized trial. Circulation 2001, 104:185-91. | Article | PubMed

97. Grigore A M, Murray C F, Ramakrishna H and Djaiani G: A core review of temperature regimens and neuroprotection during cardiopulmonary bypass: does rewarming rate matter? Anesth Analg 2009, 109:1741-51. | Article | PubMed

98. O'Donnell J, Axelrod P, Fisher C and Lorber B: Use and effectiveness of hypothermia blankets for febrile patients in the intensive care unit. Clin Infect Dis 1997, 24:1208-13. | Article | PubMed

99. Groysman L I, Emanuel B A, Kim-Tenser M A, Sung G Y and Mack W J: Therapeutic hypothermia in acute ischemic stroke. Neurosurg Focus 2011, 30:E17. | Article | PubMed

100. Sessler D I: Defeating normal thermoregulatory defenses: induction of therapeutic hypothermia. Stroke 2009, 40:e614-21. | Article | PubMed

101. Diringer M N, Bleck T P, Claude Hemphill J, 3rd, Menon D, Shutter L, Vespa P, Bruder N, Connolly E S, Jr., Citerio G, Gress D, Hanggi D, Hoh B L, Lanzino G, Le Roux P, Rabinstein A, Schmutzhard E, Stocchetti $N$, Suarez J I, Treggiari M, Tseng M Y, Vergouwen M D, Wolf S and Zipfel G: Critical care management of patients following aneurysmal subarachnoid hemorrhage: recommendations from the Neurocritical Care Society's Multidisciplinary Consensus Conference. Neurocrit Care 2011, 15:211-40. | Article | PubMed

\section{Citation:}

Sappenfield J W, Hong C M and Galvagno S M: Perioperative temperature measurement and management: moving beyond the Surgical Care Improvement Project. journal of Anesthesiology and Clinical Science 2013, 2:8. http://dx.doi.org/10.7243/2049-9752-2-8 